\title{
PENGARUH SISTEM INFORMASI AKUNTANSI DAN SISTEM PENGENDALIAN INTERNAL TERHADAP KINERJA KARYAWAN
}

\author{
Dani Sopian, Wawat Suwartika \\ Program Studi Akuntansi \\ STIE STAN Indonesia Mandiri, Jl. Jakarta No. 79 Bandung
}

\begin{abstract}
ABSTRAK
Penelitian ini bertujuan untuk menganalisis mengenai sistem informasi akuntansi dan sistem pengendalian internal terhadap kinerja karyawan baik secara parsial maupun secara simultan. Penelitian ini dilakukan pada RSUD Kota Bandung. Sampel pada penelitian ini sebanyak 49 responden dengan teknik penentuan sampel yang digunakan adalah simple random sampling. Analisis data yang digunakan dalam penelitian ini adalah analisis regresi linier berganda. Hasil penelitian ini menunjukkan bahwa secara simultan sistem informasi akuntansi dan sistem pengendalian internal berpengaruh positif tidak signifikan terhadap kinerja karyawan, secara parsial sistem informasi akuntansi berpengaruh negative tidak signifikan terhadap kinerja karyawan dan sistem pengendalian internal berpengaruh positif tidak signifikan terhadap kinerja karyawan. Hasil koefisien determinasi $\mathrm{R}^{2}$ sebesar 7,5 \% menunjukkan bahwa kinerja karyawan dapat dijelaskan oleh sistem informasi akuntansi dan sistem pengendalian internal, dan sisanya sebesar 92,5\% dijelaskan oleh variabel lain yang tidak di teliti dalam penelitian ini..
\end{abstract}

Kata Kunci : sistem informasi akuntansi, sistem pengendalian internal dan kinerja karyawan.

\section{PENDAHULUAN}

Perkembangan teknologi merupakan salah satu dampak dari perkembangan jaman. Teknologi selalu mengalami perkembangan untuk memenuhi kebutuhan manusia yang berkembang dari waktu ke waktu ( Rizaldi,2015 ). Sistem informasi akuntansi sangat diperlukan banyak pihak, baik dari dalam perusahaan maupun dari pihak luar dari dalam peusahaan misalnya manajer dan karyawan, manajer memerlukan informasi tersebut dalam kegiatan perencanaan, pengawasan dan pengendalian, sedangkan bagi karyawan informasi tersebut dapat digunakan untuk melihat prospek kerja mereka diperusahaan (Tuerah, Serny, 2013). Untuk menghasilkan kinerja yang optimal dalam suatu organisasi dapat diukur dari hasil pekerjaan yang telah dilakukan karyawan dibandingkan dengan standar yang telah di tetapkan oleh perusahaan, karena keberhasilan suatu organisasi dipengaruhi oleh kinerja karyawan. Melalui pencapaian kinerja masing-masing individu maka perusahaan dapat menghasilkan kinerja seutuhnya dan menghasilkan keberhasilan sesuai dengan apa yang di harapkan perusahaan ( Ambara \& Wayan 2016 ). 
Kinerja Karwayan menurut Sri Harti ( 2012 ) merupakan sikap yang diperhatikan individu secara nyata sebagai bentuk dari hasil kerja yang sesuai dengan tugas dan peranannya dalam organisasi. Kinerja juga merupakan tingkat keberhasilan yang dicapai oleh seseorang dalam melaksanakan tugas yang dibandingkan dengan standar kerja atau kriteria yang telah ditentukan dan disepakati sebelumnya ( Yualima \& Suhana, 2012 ). Kinerja karyawan dapat mempengaruhi tingkat keberhasilan suatu pekerjaan karena denagn hasil yang dicapai tersebut kita dapat mengetahui seberapa besar hasi kinerja seseorang. Kinerja karyawan dapat dilihat dari hasil kerja yang dicapai individu tersebut dalam melaksanakan tugas-tugas yang dibebankan kepadanya atas dasar kecakapan, pengalaman, serta keterampailan yang digunakan oleh individu dalam menyelesaikan suatu pekerjaan (Rizaldi, 2015 ).

Sistem informasi akuntansi yang menjadi suatu bagian yang sangat penting dalam sistem informasi yang dapat menerima data mentah keuangan dan memprosesnya menjadi suatu informasi untuk kepentingan baik kepentingan luar dan dalam suatu organisasi. Sistem informasi akuntansi merupakan aktifitas pendukung yang penting dalam menjalankan aktifitas utama agar lebih efektif dan efisien. Sistem informasi akuntansi tidak hanya mengolah data keuangan saja, data non keuangan juga diikut sertakan karena pengambilan keputusan tidak hanya informasi keuangan saja yang diperlukan, informasi non keuangan tentang suatu kondisi dan keadaan juga dapat dipergunakan sebagai pertimbangan dalam pengambilan keputusan. Pada perinsipnya sistem informasi akuntansi mempunyai peranan penting dalam kinerja karyawan. Menyediakan laporan keuangan yang relevan dan reliabel yang dapat digunakan sebagai informasi serta dasar untuk pengambilan keputusan adalah upaya peningkatan kinerja individu dalam sudut pandang akuntansi ( Putra, 2016 ).

Kinerja karyawan juga dapat dipengaruhi oleh sistem pengendalian internal. Pengendalian internal merupakan serangkaian kegiatan yang dilakukan oleh perusahaan untuk memberikan keyakinan yang cukup akan tercapainya tujuan perusahaan. Perusahaan pada umumnya menggunakan pengendalian internal untuk mengarahkan operasi perusahaan dan mencegah terjadinya penyalah gunaan sistem (Arsiningsih,2015). Sistem pengendalian internal berguna untuk tujuan mencegah atau menjaga terjadinya hal-hal yang tidak diinginkan ( kesalahan-kesalahan atau kecurangan -kecurangan ). Pengendalian internal berfungsi untuk mengawasi seluruh 
aktifitas ekonomi yang terjadi pada perusahaan. Pengendalian internal dapat membantu perusahaan dan berfungsi sebagai alat bantu untuk melaksanakan pengendalian dengan efektif. Dengan adanya pengendalian internal manajer dapat meyakinkan diri bahwa informasi yang terdapat dalam laporan diterima adalah benar dan dapat dipercaya (Hall 2001).

Hasil penelitian terdahulu, penelitian Rizaldi ( 2015 ) menyatakan bahwa sistem informasi akuntansi memiliki pengaruh positif dan signifikan terhadap kinerja aryawan. Penelitian lainnya Kasandra 2016 menunjukkan bahwa sistem informasi akuntansi berpengaruh signifikan pada kinerja karyawan. Sedangkan Soudani ( 2012 ) menunjukkan hasil yang berbeda tentang hasil penelitian sistem informasi akuntansi berpengaruh tidak signifikan terhadap kinerja karyawan.

Penelitian mengenai sistem pengendalian internal yang dilakukan Usman (2013) menunjukkan bahwa sistem pengendalian internal berpengaruh signifikan terhadap kinerja karyawan. Pada penelitian oleh Asrini (2015) menunjukkan bahwa terdapat pengaruh yang positif dan signifikan antara pengendalian internal terhadap kinerja karyawan.

\section{Identifikasi Masalah}

Berdasarkan uraian di atas, identifikasi masalah dalam penelitian ini adalah :

1. Apakah Sistem informasi akuntansi berpengaruh signifikan terhadap kinerja karyawan?

2. Apakah Sistem pengendalian internal berpengaruh signifikan terhadap kinerja karyawan?

3. Apakah Sistem informasi akuntansi dan Sistem pengendalian internal secara bersama-sama berpengaruh signifikan terhadap kinerja karyawan?

\section{REVIEW LITERATUR \& PENGEMBANGAN HIPOTESIS}

Triandis (1980) dalam Amalia (2010) menyatakan bahwa perilaku ditentukan oleh apa yang orang-orang ingin lakukan (sikap), apa yang mereka pikirkan akan mereka lakukan (aturan-aturan sosial), apa yang mereka bisa lakukan (kebiasaan) dan dengan konsekuensi perilaku yang mereka pikirkan. Sikap merupakan sebuah bangunan hipotesis yang mewakili suatu derajat individu dari suka atau tidak suka untuk item. 


\subsection{Pengertian Kinerja Karyawan}

Menurut Mangkunegara (2008) dalam Rizaldi (2015) mengatakan bahwa kinerja adalah hasil kerja secara kualitas dan kuantitas yang dicapai oleh seorang pegawai dalam melaksanakan tugasnya sesuai dengan tanggung jawab yang diberikan kepadanya. Pencapaian kinerja yang tinggi akan memberikan kepuasan bagi individu sehingga individu tersebut dapat termotivasi untuk selalu berusaha mencapai kinerja yang tinggi dalam melaksanakan pekerjaannya. Kinerja adalah pelaksanaan suatu pekerjaan dan penyempurnaan pekerjaan tersebut sesuai dengan tanggung jawabnya sehingga dapat mencapai hasil sesuai dengan yang diharapkan. Definisi ini menunjukkan bahwa kinerja lebih ditekankan pada proses, gimana selama pelaksanaan pekerjaan tersebut dilakukan penyempurnaan-peneyempurnaan sehingga pencapaian hasil pekerjaan atau kinerja dapat dioptimalkan (Sinambela, $2012: 5$ ).

Menurut Tika (2006) Kinerja karyawan merupakan perilaku yang secara langsung berhubungan dengan produksi atau penyampaian jasa. Informasi tentang kinerja meruapakan suatu hal yang sangat penting digunakan untuk mengevaluasi apakah proses kinerja yang dilakukan selama ini sudah sejalan dengan tujuan yang diharapkan atau belum. Kinerja sebagai hasil - hasil fungsi pekerjaan seseorang atau kelompok dalam suatu organisasi yang dipengaruhi oleh berbagai faktor untuk mencapai tujuan organisasi dalam periode waktu tertentu.

Pengertian Kinerja karyawan menurut Rivai (2005 : 15-17) adalah kesediaan seseorang untuk melakukan suatu kegiatan dan menyempurnakannya sesuai dengan tanggung jawabnya dengan hasil seperti yang diharapkan. Jika dikaitkan dengan performance sebagai kata benda (noun) dimana salah satu entrynya adalah hasil dari suatu pekerjaan (think done), pengertian performance atau kinerja adalah hasil kerja yang dapat dicapai oleh seseorang dalam suatu perusahaan sesuai dengan wewenang dan tanggung jawab masing-masing dalam upaya pencapaian tujuan perusahaan secara legal, tidak melanggar hukum dan tidak bertentangan dengan moral atau etika

\subsection{Pengertian Sistem informasi akuntansi}

Menurut Susanto, Azhar (2013 : 8) akuntansi pada dasarnya merupakan sistem informasi, yang membedakan sistem informasi dengan sistem informasi lainnya adalah sistem informasi (akuntansi) atau disebut juga sebagai sistem informasi hanya berkaitan dengan fungsi akuntansi dalam mengelola data tentang aktivitas organisasi perusahaan 
yang menilai ekonomi. Jadi sistem informasi akuntansi hanya mengolah data yang memilki dampak ekonomi. Kebanyakan data akuntansi yang diolah oleh sistem informasi akuntansi disajikan dalam bentuk jumlah uang atau bentuk lain yang terkait atau dapat dikonversikan ke dalam jumlah uang.

Sedangkan menurut James A, Hall (2001 : 10) Sistem informasi akuntansi adalah sistem yang terdiri dari tiga sub sistem yaitu transaction processing system, general ledger / financial reporting system, management reporting system. Menjelaskan bahwasistem informasi akuntansi adalah kesatuan struktur - struktur dalam suatu entitas, seperti perusahaan bisnis yang memperkerjakan sumber- sumber daya fisik dan komponen - komponen lain untuk mentransformasi data ekonomi menjadi informasi akuntansi, dengan tujuan untuk memuaskan kebutuhan para pemakai informasi yang bervariasi.

Sistem informasi akuntansi adalah suatu sistem yang melaksanakan berbagai operasi dalam rangka menghasilkan informasi yang relevan, diantaranya mencatat data ekonomi, memproses dan menganalisa data serta menyajikan informasi kuantitatif dalam bentuk laporan keuangan ( Rafis, 2013). Sistem informasi akuntansi adalah sebagai sumber daya seperti peralatan dan manusia yang diatur guna mengubah data hingga menjadi informasi. Sistem informasi akuntansi dibuat oleh suatu perusahaan untuk memenuhi fungsinya guna menghasilkan informasi akuntansi yang relevan, tepat waktu dan dapat dipercaya. Dalam sistem informasi akuntansi mengandung unsur pengendalian sehingga dapat berperan sebagai alat pengendalian internal. Salah satu yang dijadikan objek pengendalian adalah kinerja pegawai ( Bodnar \& Hopwood, 2003:23).

\subsection{Sistem pengendalian internal}

Strategi manajemen yang tepat dan sesuai sangat dibutuhkan dalam pengelolaan sumber daya yang dimiliki perusahaan untuk mencapai tujuan yang ingin dicapai oleh perusahaan yaitu memperoleh laba. Meningkatnya laba dan kualitas produk dan jasa serta pelayanan suatu perusahaan juga tidak lepas dari pengaruh kinerja karyawan yang baik. Kinerja karyawan dikatakan baik apabila perusahaan mampu mengatur serta mengembangkan sumber daya yang dimiliki dan mencapai target yang telah ditetapkan oleh perusahaan (Citrawati, 2011:2). 
Sistem pengendalian internal adalah sistem usaha atau sistem sosial yang dilakukan perusahaan yang teridiri dari struktur organisasi, metode dan ukuran-ukuran untuk menjaga dan mengarahkan jalan perusahaan agar bergerak sesuai dengan tujuan dan program perusahaan dan mendorong efisiensi serta dipatuhi kebijakan manajemen. Sistem pengendalian internal yang handal dan efektif dapat memberikan informasi yang tepat bagi manajer maupun dewan direksi yang bagus untuk mengambil keputusan maupun kebijakan yang tepat untuk pencapaian tujuan perusahaan yang lebih efektif pula. Sistem pengendalian internal berfungsi sebagai pengatur sumber daya yang telah ada untuk dapat difungsikan secara maksimal guna memperoleh pengembalian ( gaint) yang maksimal pula dengan pendekatan perancangan yang menggunakan asas cost benefit, (Indah 2012).

\subsection{Hubungan sistem informasi akuntansi terhadap kinerja karyawan}

Kinerja individu karyawan sangat mempengaruhi keberhasilan sebuah perusahaan, diharapkan individu dapat menyelesaikan tugasnya tepat waktu dengan teknologi sistem informasi akuntansi yang relevan artinya dapat menambah pengetahuan bagi para pengguna sistem tersebut, dapat dipercaya artinya informasi yang dihasilkan bebas dari kesalahan atau bias yang secara jelas menggambrakan kejadian atau aktivitas pekerjaan tersebut, lengkap artinya data penting yang dibutuhkan pengguna tedapat pada sistem tersebut, tepat waktu artinya laporan yang dihasilkan dapat disajikan pada saat dibutuhkan oleh penggunanya,mudah di pahami artinya disajikan dalam format yang mudah dimengerti dan dapat diuji kebenarannya artinya menghasilkan informasi yang sama secara independen.

Sistem informasi dalam perusahaan adalah faktor penting dalam pencapaian kinerja. Semakin baik sistem informasi akuntansi maka pengguna sistem informasi akuntansi akan merasa puas jika sistem informasi akuntansi meningkat maka kinerja karyawan akan meningkat.

\subsection{Hubungan sistem pengendalian internal terhadap kinerja karyawan}

Sistem pengendalian internal yang efektif akan berpengaruh terhadap kinerja karyawan suatu perusahaan karena suatu perusahaan akan beroperasi dengan baik apabila perusahaan tersebut menggunakan sistem pengendalian internal dan prosedur yang baik dengan adanya sistem pengendalian internal dapat mengendalikan jalannya 
perusahaan yang mencakup dan mengamankan harta,memeriksa kecermatan dan kebenaran administrasi atau akuntansi,memajukan efisiensi dalam operasi dan membantu menjaga kebijaksanaan perusahaan untuk dipatuhi selain itu dengan adanya sistem pengendalian internal dapat menjaga kekayaan dan catatan perusahaan, mengecek ketelitian dan keandalan data akuntansi, mendorong efisiensi dengan menggunakan sumber daya dan sarana,secara berdaya guna dan berhasil guna, mendorong dipatuhinya kebijakan manajemen. Dengan adanya sistem pengendalian internal dalam suatu perusahaan diharapkan adanya : penempatan karyawan yang mutunya sesuai dengan tanggung jawabnya, adanya peraktik yang sehat dalam melaksanakan tugas dan fungsi setiap unit,sistem wewenang dan prosedur pencatatan yang memberikan perlindungan yag cukup terhadap aktiva, utang, pendapatan dan biaya serta adanya struktur organisasi yang memisahan tanggung jawab fungsional secara tegas.

Sistem pengendalian inetrnal dalam perusahaan adalah faktor penting dalam pencapaian kinerja. Tercapainya sistem pengendalian internal yang baik dalam suatu perusahaan tentu saja akan meningkatan kinerja para karyawan.

\subsection{Model Analisis}

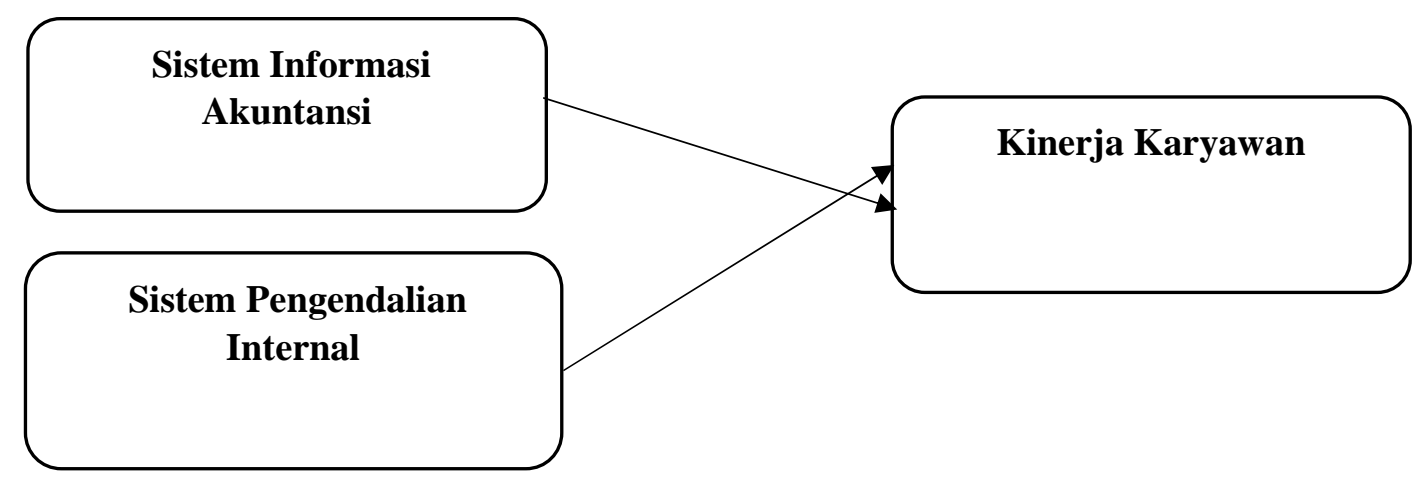

Gambar 2.1 Model Analisis 


\subsection{Hipotesis}

Berdasarkan model analisis, dapat dikemukakan hipotesis penelitian sebagai berikut :

H1 : Sistem informasi akuntansi memiliki pengaruh signifikan terhadap Kinerja Karyawan.

H2 : Sistem pengendalian internal memiliki pengaruh positif terhadap Kinerja Karyawan.

\section{METODE DAN PROSEDUR PENELITIAN}

\subsection{Unit Analisis}

Menurut Indriantoro \& Supomo (1999: 94) unit analisis merupakan tingkat agresi data yang dianalisis dalam penelitian. Unit analisis yang ditentukan berdasarkan pada rumusan masalah atau pertanyaan penelitian, merupakan elemen yang penting dalam design penelitian karena mempengaruhi proses pemilihan, pengumpulan data, dan analisis data. Studi ini mengkaji mengenai hubungan system informasi akuntansi dan pengendalian internal terhadap kinerja karyawan, maka unit analisisnya adalah karyawan yang menggunakan sistem informasi akuntansi yang bekerja pada RSUD Kota Bandung.

\subsection{Populasi dan Sampel}

Populasi pada studi ini adalah seluruh karyawan yang menggunakan teknologisistem informasi akuntansi di RSUD Kota Bandung dan Sampel dalam studi ini adalah karyawan yang menggunakan sistem informasi akuntansi di RSUD Kota Bandung.

\section{TEMUAN - TEMUAN}

\subsection{Pengaruh Sistem Informasi Akuntansi dan Sistem Pengendalian Internal terhadap Kinerja Karyawan}

Hasil dari penelitian ini secara simultan dengan uji $\mathrm{F}$ menunjukkan bahwa variabel independen yaitu sistem informasi akuntansi (SIA) berpengaruh negatif tidak signifikan terhadap kinerja karyawan (KK) sedangkan sistem pengendalian internal (SPI) berpengaruh positif tidak signifikan terhadap kinerja karyawan (KK). Penjelasan mengenai hal tersebut dapat dijabarkan sebagai berikut, alasannya karena karyawan 
tidak mudah dalam menerima, memahami dan memanfaatkan sistem informasi akuntansi serta bisa menyesuaikan diri dengan sistem yang digunakan sedangkan untuk sistem pengendalian internal walaupun sistem pengendalian internal yang diterapkan sudah bagus namun belum digunakan secara efektif karena laporan keuangan yang dipublikasikan oleh karyawan (staff akuntansi \& keuangan ) sudah baik dan dapat dipercaya ,prosedur dan peraturan yang telah ditetapkan oleh perusahaan juga sudah di taati dan dipatuhi dengan semestinya.

Keberhasilan sistem informasi akuntansi didalam suatu perusahaan tergantung bagaimana sistem itu dijalankan dan digunakan sehingga memberikan kemudahan bagi para pemakainya. Sistem informasi akuntansi yang diimplementasikan didalam perusahaan seharusnya dapat memberikan manfaat pada kinerja individu setiap karyawan dan organisasi serta memberikan kenyamanan bagi para pemakainya, sehingga sistem informasi akuntansi tersebut dapat dimanfaatkan dengan baik didalam perusahaan.

\subsection{Pengaruh SistemInformasi Akuntansi terhadap Kinerja Karyawan}

Hasil dari pengujian hipotesis yang pertama menunjukkan bahwa sistem informasi akuntansi berpengaruh tidak signifikan terhadap kinerja karyawan. Penjelasan mengenai hal tersebut dapat dijabarkan sebagai berikut, alasannya karena sistem informasi akuntansi yang di manfaatkan oleh pengguna tersebut belum relevant, reliable, complete, timely, understandable, dan diferivikasi sehingga sistem informasi akuntansi berpengaruh tidak signifikan terhadap kinerja karyawan.

Semakin tinggi ekspektasi kinerja maka semakin tinggi pula minat sistem informasi akuntansi dapat digunakan oleh setiap karyawan, ekspektasi kinerja berpengaruh pada sistem informasi akuntansi, artinya seseorang yakin bila sistem informasi akuntansi akan membantu mereka dalam meningkatkan kinerjanya (Trisna \& Wiratmaja, 2015).

Untuk meningkatkan minat sistem informasi akuntansi maka dapat dilakukan dengan meyakinkan para pengguna sistem informasi akuntansi bahwa dengan sistem informasi akuntansi akan membantu meningkatkan kinerja mereka. Perusahaan harus menjamin sistem informasi akuntansi akan memberikan manfaat bagi karyawannya. Perusahaan juga harus menjamin sistem informasi akuntansi akan meningkatkan produktivitas efektivitas serta kualitas output pekerjaan mereka. Saat perusahaan bisa 
menjamin hal tersebut maka minat sistem informasi akuntansi karyawan juga akan meningkat.

\subsection{Pengaruh Sistem Pengendalian Internal terhadap Kinerja Karyawan}

Hasil dari pengujian hipotesis kedua dapat dijelaskan sebagai berikut, Sistem pengendalian internal adalah suatu sistem usaha atau sistem sosial yang dilakukan perusahaan yang terdiri dari struktur organisasi, metode dan ukuran-ukuran untuk menjaga dan mengarahkan jalan perusahaan agar bergerak sesuai dengan tujuan dan program perusahaan dan mendorong efesiensi serta dipatuhi kebijakan manajemen. Sistem pengendalian inetrnal yang handal dan efektif dapat memberikan informasi yang tepat bagi manajer maupun dewan direksi yang bagus untuk mengambil keputusan maupun kebijakan yang tepat untuk pencapaian tujuan perusahaan yang efektif pula. Sistem pengendalian internal adalah untuk menghindari adanya penyimpangan dari prosedur, laporan keuangan yang dihasilkan dari perusahaan, dapat dipercaya dan kegiatan perusahaan sejalan dengan hukum dan peraturan yang berlaku. Selain itu sistem pengendalian internal adalah untuk meningkatkan kinerja karyawan ,untuk melindungi harta/aktiva perusahaan dan pencatatan pembukuannya, sistem pengendalian internal digunakan untuk mengecek kecermatan dan keandalan data akuntansi, meningkatkan efisensi usaha dan mendorong ditaatinya kebijakan manjemen yang telah ditetapkan. Maka dari untuk tercapainya sistem pengendalian internal perusahaan yang baik tentu saja akan meningkatkan produktivitas serta kinerja para karyawan. Hasil kerja yang dapat dicapai oleh karyawan sesuai dengan wewenang dan tanggung jawab masing-masing, dalam rangka mencapai tujuan perusahan bersangkutan secara legal, tidak melanggar hukum dan sesuai dengan moral maupun etika. Sistem Pengendalian merupakan kebijakan dan prosedur yang melindungi aktiva dari penyalahgunaan, memstikan bahwa informasi akurat dan memastikan bahwa perundang-undangan serta peraturan dipatuhi sebagaimana mestinya.

\subsection{Koefisien Determinasi}

Hasil nilai koefisien determinasi ( $\mathrm{R}$ square) adalah sebesar $0,075 \%, \mathrm{R}$ square digunakan untuk mengetahui sebarapa jauh kemampuan model dalam menerangkan variasi variabel dependen, nilai ini menunjukkan bahwa variasi nilai kinerja karyawan yang dapat dijelaskan oleh model regresi sebesar $0,075 \%$ sedangkan sisanya yaitu 
99,925\% dijelaskan oleh variabel lain diluar model. Artinya perubahan - perubahan pada variabel dependen dapat dijelaskan sebesar 0,075 \% yang dipengaruhi oleh variabel independen yaitu sistem informasi akuntansi dan sistem pengendalian inetrnal.

Serta sisanya sebesar 99,925\% dijelaskan oleh faktor - faktor lain yang tidak diteliti pada penelitian ini. Seperti kualitas sistem informasi akuntansi, kemudahan penggunaan sistem, pemanfaatan informasi, kinerja sistem informasi akuntansi, kepuasan pengguna sistem informasi akuntansi, kepercayaan teknologi sistem informasi, atau variabel lainnya. Berdasarkan nilai $\mathrm{R}$ square sebesar 0,075\% artinya pengaruh antara variabel pemanfaatan sistem informasi akuntansi dan penerapan sistem informasi akuntansi terhadap kinerja karyawan adalah bernilai kecil artinya kemampuan dependen sangat terbatas, yang disebabkan oleh variabel - variabel independen yang belum memberikan informasi yang dibutuhkan untuk memprediksi variabel dependen.

\section{KESIMPULAN}

Berdasarkan penelitian yang telah dilakukan oleh penulis, penelitian ini bertujuan untuk menguji apakah sistem informasi akuntansi dan sistem pengendalian internal berpengaruh positif signifikan terhadap kinerja karyawan pada RSUD Kota Bandung. Dari data yang diperoleh, maka penulis menarik kesimpulan sebagai berikut

1. Hasil pengujian secara simultan menyatakan bahwa sistem informasi akuntansi dan sistem pengendalian inetrnal berpengaruh positif tidak signifikan terhadap kinerja karyawan. Hal ini disebabkan karena sistem informasi akuntansi yang diimplementasikan/diterapkan di perusahaan yang memberikan manfaat pada kinerja individu setiap karyawan tidak digunakan dan dimanfaatkan oleh karyawan tersebut begitu pula dengan sistem pengendalian internal yang belum sepenuhnya diaplikasikan dalam setiap kegiatan pelaporan keuangan perusahaan.

2. Hasil pengujian secara parsial sistem informasi akuntansi terhadap kinerja katyawan adalah berperpengaruh negatif tidak signifikan terhadap kinerja karyawan. Hal ini disebabkan karena pada sistem informasi akuntansi karyawan belum dapat memanfaatkan sistem informasi akuntansi dengan baik serta belum menyesuaikan diri dalam melaksanakan tugasnya dengan menggunakan sistem tersebut sehingga sistem informasi akuntansi tidak berpengaruh terhadap kinerja karyawan Artinya, keberhasilan sistem informasi akuntansi tergantung bagaimana sistem itu digunakan 
dan dijalankan bagi pemakainya serta pemanfaatan sistem informasi akuntansi yang digunakan pada perusahaan tersebut.

3. Sedangkan dalam sistem pengendalian internal hasil pengujian secara simultan menyatakan bahwa sistem pengendalian internal berpengaruh positif tidak signfikan terhadap kinerja karyawan. Hal ini disebabkan karena walaupun sistem pengendalian internal yang diterapkan sudah bagus namun belum digunakan secara efektif karena laporan keuangan yang dipublikasikan oleh karyawan (staff akuntansi \& keuangan ) sudah baik dan dapat dipercaya ,prosedur dan peraturan yang telah ditetapkan oleh perusahaan juga sudah di taati dan dipatuhi dengan semestinya. Artinya karyawan dapat menyusun laporan keuangan dengan baik dan handal tanpa menggunakan sistem pengendalian internal dan juga adanya keterbukaan dalam proses pengambilan keputusan dan keterbukaan dalam mengemukakan informasi materiil dan relevan mengenai perusahaan .

4. Nilai koefisien determinasi ( $\mathrm{R}$ square) adalah $0,075 \%$ artinya perubahan pada variabel dependen dapat dijelaskan sebesar $0,075 \%$ yang dipengaruhi oleh variabel independen yaitu sistem informasi akuntansi dan sistem pengendalian internal. Sedangkan sisanya sebesar 99,925\% dijelaskan oleh faktor - faktor yang tidak diteliti pada penelitian ini.

\section{DAFTAR PUSTAKA}

Anggraini, Trisye Yeni. 2011. Sistem Informasi Akuntansi Terhadap Kinerja Manajerial pada Perusahaan Retail di Surabaya. Surabaya: STIE Perbanas.

Anwar ,Sariyun Naja. 2009. Pengaruh Kematangan Teknologi Informasi Dan Kinerja Sistem Informasi Terhadap Kemanfaatan Sistem Informasi Bagi KelurahanKelurahan Di Kodia Semarang.Jurnal Teknologi Informasi Dinamik Vol. Xiv, No.2.Semarang (2009): Fakultas Teknologi Informasi, Universitas Stikubank.

Cintya, Sari. 2017. Pengaruh Kualitas SIA dan Pemanfaatan Teknologi Informasi terhadap Kinerja Karyawan Studi Pada Bank Umum Kota Bandung. STIE STANIM.

Hakim, Abdul. 2006. Analisis Pengaruh Motivasi, Komitmen Organisasi dan IklimOrganisasi Terhadap Kinerja Pegawai Pada Dinas Perhubungan danTelekomunikasi Provinsi Jawa Tengah. JRBI. Vol 2. No 2. Hal: 165-180.

Indriantoro dan Sopomo. 1999. Metodologi Penelitian Bisnis untuk Akuntansi dan Manajemen. Edisi Pertama. Yogyakarta: BPFE Yogyakarta. 
Irfiani, Eni. 2016. Pengaruh Penggunaan Sistem Informasi terhadap Kinerja Karyawan. Vol. XVII. September (2015): No.2.

Jin, Fung Tjhai. 2003. Analisis Faktor-Faktoryang Mempengaruhi Pemanfaatan Sisteminformasi dan sistem informasi dan teknologiinformasi dan Pengaruh Pemanfaatan Sisteminformasi dan sistem informasi dan teknologiinformasi terhadap Kinerja Akuntan Publik. Jurnal Bisnis dan Akuntansi. Vol. 5 (2003): No.1.

Kadek Wahyu Indralesmana \& I.G.N. Agung Suaryana. 2014. Pengaruh Penerapan Informasi Akuntansi terhadap Kinerja Individu Pada Usaha Kecil dan Menengah Di Nusa Penida. E-Jurnal Akuntansi Universitas Udayana. Vol. 8.1. (2014) :1426.

Kasandra, Ni Made Ayu Ari \& Gede, Juliarsa. 2016. Pengaruh Kualitas Penerapan SIA, Pemanfaatan dan Kepercayaan Teknologi Informasi terhadap Kinerja Karyawan. Vol 14.1. Januari (2016): 539-547.

Lukiman, Renaldy \& Lestarianto, Widodo. 2016. Pengaruh Penerapan Sistem Informasi Akuntansi, Pemanfaatan Sistem Informasi, Efektivitas Penggunaan Sistem Informasi Akuntansi dan Teknologi Informasi terhadap Kinerja Individu Karyawan. Ultima Accounting. Vol. 8. Desember (2016): No. 2.

Made, Ambara Dita \& I Wayan, Putra. 2016. Pengaruh Penerapan Sistem Informasi Akuntansi terhadap Kinerja Karyawan dengan Integritas Karyawan sebagai Variabel Pemoderasi. Vol.15.1 April (2016): 614-640.

Mahardhika, Arya. 2013. Pengaruh Penerapan Sistem Informasi Akuntansi dan Karakteristik Individu terhadap Kinerja Karyawan BMT di Yogyakarta. Fakultas Ekonomi: Universitas Islam Indonesia Yogyakarta.

Mardiani, Dwi. 2017. Pengaruh Penerapan Sistem Informasi Akuntansi dan Komitmen Organisasi terhadap Kinerja Pengguna Studi terhadap Pengguna SIA di Institut Teknologi Bandung. STIE STAN-IM.

Margono. 2004. Metodologi Penelitian Pendidikan. Jakarta: Rineka Cipta.

Masrukhin \& Waridin. 2004. Pengaruh Motivasi Kerja, Kepuasan Kerja, BudayaOrganisasi Dan Kepemimpinan Terhadap Kinerja Pegawai. EKOBIS. Vol 7. No2. Hal: 197-209.

Mindiyanto, Arry. 2013. Sistem Informasi Akuntansi dan Teknologi Informasi Pengaruh terhadap Kinerja Karyawan Instansi Pada Perusahaan Daerah Kebersihan Kota Bandung. STIE STAN-IM.

Periyanti \& Effendi, Rizal. 2013. Pengaruh Pemanfaatan Sistem Informasi Akuntansi terhadap Kinerja Manajerial Pada Showroom di Kota Palembang. Jurusan Akuntansi : STIE MDP.

Puji, Astuti, N. \& Dharmadiaksa, I. B. 2014. Pengaruh Efektivitas Penerapan Sistem Informasi Akuntansi, Pemanfaatan dan Kesesuaian Tugas Terhadap Kinerja Karyawan. E-Jurnal Akuntansi Universitas Udayana, 9(2), h:373-384. 
Raflis, Riri Yulianti. 2012. Pengaruh Pelatihan Dan Dukungan Manajemen Puncak Terhadap Penerapan Sistem Informasi Akuntansi. Artikel Ilmiah, Padang: Universitas Negeri Padang.

Rama \&Jones. 2007. Sistem Informasi Akuntansi. Buku 1 Edisi 1. Jakarta: Salemba Empat.

Rizaldi, Fahmi\&Suryono, Bambang. 2015. Pengaruh Sistem Informasi Akuntansi terhadap Kinerja Karyawan. Vol. 4 (2015): 10.

Soudani, Siamak Nejadhosseini. 2012. The Usefulness of an Accounting Information System for Effective Organizational Performance. International Journal of Economics and Finance. 4(5) pp: 136-143.

Suhud, Sheilla Puteri. 2015. Pengaruh Penerapan Sistem Informasi Akuntansi Terhadap Kinerja Individu Pegawai Disro di Kota Bandung. Skripsi S-1 Jurusan Akuntansi Universitas Diponegoro.

Susanto, Azhar. 2013. Sistem Informasi Akuntansi: Struktur-Pengendalian-ResikoPengembangan. Bandung: Lingga Jaya.

Tata, Sutabri. 2005. Sistem Informasi Manajemen. Yogyakarta: Andi Ypgyakarta.

Tika, P. 2006. Budaya Organisasi Dan Peningkatan Kinerja Perusahaan. Jakarta: BumiAksara.

Tuerah, Sernny. 2013. Evaluasi Efektivitas Sistem Informasi Akuntansi Pembelian dan Pengeluaran Kas (Pada UD. Roda Mas Manado). Vol.1. September (2013): No.3: 225-232.

Yualina, Riastuti P. \& Suhana. 2012. Efektivitas Motivasi Kerja Dalam Meningkatkan Kinerja Pegawai. Buletin Pengelolaan Reaktor Nuklir, 9 (2), h: 57 - 65. 